\title{
O loteamento de terrenos urbanos de proprie- dade particular e o dominio público dos espaços livres
}

1. O afluxo, que ultimamente se há verificado, quase que em todo o mundo, das populações rurais para os centros urbanos, aumentando, às vezes imprevistamente, as necessidades da cohabitação, trouxe como consequência natural o descongestionamento, provocado pelas empresas que, aqui como acolá, entraram a explorar a indústria dos loteamentos de terrenos, nos arrabaldes ou subúrbios. Criou-se essa indústria diante da impossibilidade dos poderes públicos municipais de enfrentarem o problema e darem-lhe a solução adequada e até premente. No começo, tudo correu desordenadamente, de acôrdo com o capricho ou com as conveniências dos loteadores profissionais, mais preocupados com o seu interesse de lucro do que com o atendimento das condições de higiene ou de estética, quando não das econômicas e sociais, que confluem para a complexidade do aspecto urbanistico. Tudo isso, como é de imaginar, exigiu a interferência do poder público, a bem da coletividade, e o estabelecimento de norma: gerais a que os loteamentos se subordinariam, sob a égide da lei.

Prefaciando monografia a que mais de uma vez nos referiremos linhas adiante, WiLliam Oualid, professor da Faculdade de Direito de Paris e diretor adjunto do Ins- 
tituto de Urbanismo da Universidade de Paris, doutrinou que "todo ato individual em matéria de serviço urbano é prenhe de consequências para a coletividade. Deve esta, por isso mesmo, estar atenta no prevenir os males de iniciativa inconsiderada e unicamente guiada pelo ânimo de lucro. Deve ela recorrer a varios meios, quer os autoritários e regulamentares, quer os persuasivos e acoroçoadores. Como autoridade administrativa, tem ela poderes para obrigar os particulares à observância de certas regras: alinhamento, largura das ruas, espaços livres, insolamento, orientação dos imóveis, etc. Como autoridade econômica, representando os interesses coletivos, póde ela e deve usar de sua faculdade de intervir, ajudando financeiramente as emprêsas ou serviços de natureza econômica, mercantil ou industrial. Torna-se a autoridade pública, dessarte, associada aos interêsses privados. Deixa ela a êstes a iniciativa, os riscos, parte do lucro, mas, ao mesmo tempo, impede que se tornem, por degenerescência, em motores únicos da atividade, desconhecendo o interêsse geral". Este há de estar sempre presente no espírito e no programa de quantos, usurpando atribuições que deveriam ser sempre, e necessariamente, do âmbito do poder público, tomam sôbre si a responsabilidade de empreendimentos em que prima o interêsse da coletividade.

Eis porque, na França, como na Alemanha, e em outros paises, leis se promulgaram, de molde a disciplinar a atividade dos industriais de loteamentos de terrenos urbanos. Quando, em França, em 192A, se apresentou, no Parlamento, o projeto de lei reguladora dos loteamentos o relator dêste resumiu o sistema, que se elaborava, acentuando que os loteamentos se caracterizavam especificamente por três pontos fundamentais: a) a divisão dos terrenos em parcelas; $b$ ) a intenção do proprietário de vender ou alugar as parcelas; c) a abertura de ruas novas. E tratadista observou haver aquele deputado omitido um dos mais importantes pontos, o que contém toda 
a razão de ser da lei - a edificação de construções para o uso de habitação (1).

2. Quando o proprietário de terreno que entesta com via, rua ou praça pública, divide-o em lotes com frente para a via, rua ou praça pública, a fim de vendê-los para a construção de prédios de qualquer natureza, êsse loteamento não apresenta os mesmos aspectos que o do loteamento destinado à criação de novos bairros ou quarteirões, dotados de ruas e praças internas, ou externas, constituindo blócos urbanisticos — as chamadas vilas ou jardins de algumas grandes cidades brasileiras. Se a cada um é licito usar, gozar e dispồ de sua propriedade $\mathrm{e}$, assim, dividíla em lotes, como melhor lhe convenha, mas ainda assim em consonância com as leis e regulamentos municipais; os adquirentes destes lotes somente poderão aproveitá-los para as construções adequadas com observancia daquelas posturas, que podem, e devem, determinar as condições mediante as quais são possiveis os loteamentos de terrenos urbanos.

E de notar que, a propósito da lei francêsa de 1924, vircular ministerial da época salientou que "todas as vezes que todas as parcelas de terreno para construção fossem adjacentes a vias de comunicações públicas ou privadas, providas de agua e de meios de evacuação das matérias usadas, o proprietário desse terreno se submeteria às prescrições da lei de 1924; mas se, ao contrário, tôdas as parcelas não contassem com aquelas três vantagens, aquela lei lhes não seria aplicável" (2).

Não concordou com essa interpretação a jurisprudência. Dois julgados da Câmara Criminal da Côrte de Cassação, de 27 de junho de 1929, firmaram, um que,

(1) J. Cazenavette, Extension des Villes et Lotissements, ed. du Recueil Sirey (Paris, 1936), pág. 46.

(2) Maurice Polti, Traité Théorique et Pratique sur les Lotissements, ed. de Boccard (Paris, 1926), pág. 188. 
"para que haja realização de loteamento nos termos da lei 1919-1924, é bastante que exista a venda de terrenos em lotes para edificação de habitações"; e outro, que "as obrigações impostas pelos arts. 11,12 e 13 da lei de 1919-1924 não comportam exceção, e a circunstância de que os terrenos oferecidos à venda sejam situados à margem de caminho de grande comunicação não póde ter outro efeito senão o de constranger o vendedor a preprar seus projetos de loteamentos com respeito das obrigações impostas pelas leis de 5 de abril de 1884 e de 15 de fevereiro de 1902" (3).

3. Não se deve perder de conta, para que bem se aprecie o problema do loteamento de terrenos particulares para o efeito de sua venda para construções urbanas, que o proprietário, que toma tal iniciativa e a leva a cabo, se propõe transmudar o objeto de seu direito de propriedade, aproveitando-se desta para a realização de lucro de seu inteiro proveito, mas realizando, inequivocamente, obra ou serviço público.

No loteamento compreendem-se, em sua maior parte, os lotes destinados à venda. Ésses, o proprietario conserva em seu dominio, a fim de revendê-los e dessa operação tirar os lucros do empreendimento. Para que, todavia, os lotes assim reservados sejam suscetiveis de venda e de aproveitamento adequado, o loteador terá que abrir ruas e praças e, em muitos paises, de reservar os lotes necessários para escolas, hospitais, igrejas, etc., e que constituem os chamados - espaços livres. Esses espaços livres destinam-se a incorporar-se à cidade, integrando-se no patrimônio municipal, de tal arte que, vendidos todos os lotes e alcançado, por essa fórma, o escôpo industriai do loteador, êles se transmudam, definitivamente, no pa-

(3) J. Cazenavette, Exiension des Villes et Lotissements, ed Recueil Sirey (Paris, 1936), pág. 50. 
trimônio público, desaparecendo, por completo, o interêsse do loteador, que realizou o seu programa industrial. Ha. verá, quando muito, a examinar o problema da indenização, pelo poder municipal, daqueles terrenos, que formam os espaços livres, pois que, nos termos do art. 141, paragr. 16, da Constituição do Brasil, é garantido o direito de propriedade, salvo o caso de desapropriação por necessidade ou utilidade pública, ou por interêsse social, "mediante prévia e justa indenização em dinheiro".

Tocou a lei francêsa no ponto, estabelecendo, no paragar. 9 do art. 11, que "le maire ou, ià son dêfaut, le prefét pourra exiger la réserve d'espaces libres (places, terrains de jeux, etc.) et d'emplacements destinés a des édifices et services publics. Les terrains réservés pour les édifices et services publics donneront lieu $\dot{a}$ indemnité. Ceux réservéspour les espaces libres et les voies donneront également lieu à indemnité lorsque leur ensemble representera une surface supérieure à celle qui résulterait de l'application des règlements et du projet d'aménagement et d'extension de la commune. Cette surface ne pourra être inférieure au quart de la surface totale da lotissement."

Como do texto resulta, a parte destinada às praças, terrenos para jogos ou vias de comunicações, etc., que passará na medida determinada a pertencer à comuna, não se compensará com nenhuma indenização, pois que se dará, como observou tratadista, "l'abandon sans indeinnité et obligatoirement du quart de la superficie", que poderá ser, em alguns casos, "exagérée et injuste à l'egard des lotisseurs" (4).

Não se dá, propriamente, a expropriação compulsória; mas é que, sendo impossivel realizar o plano do loteamento sem os espaços livres as praças, jardins, ruas, vias

(4) AmÉdÉE Bonde, Traité Pratique de l'Aménagement, de l'Extension, de l'Embellissement des Villes et des Lotissements, ed. Dalloz (Paris, 1927), pág. 261, n. 152. 
de comunicações em geral, a bem dos eventuais adquirentes dos lotes, tudo isso se torna indispensavel e entra na categoria dos encargos a cargo do loteador. Óbvio é que êste, no calcular os preços de vendas dos lotes, há de computar, necessariamente, todas as despesas com que terá de arcar, incluindo nelas os preços dos espaços livres, de que se reembolsará à custa dos futuros proprietários, que os usfruirão. Não se dará, portanto, nenhum enriquecimento ilicito ou injusto por parte da comuna, sôbre a qual recairão os encargos futuros de conservação, asfaltamento, reparos e manutenção. Opéra em tudo a lei das compensações, mercê da qual os espaços livres das praças, ruas, jardins, etc. accedem ao patrimonio comunal, libertando-se os loteadores daqueles encargos, a que ficariam sujeitos se continuassem êles na sua propriedade particular. Eis o prisma atravez do qual o problema dos loteamentos urbanos tem que ser examinado.

4. Entre outras, destaca-se a lei marroquina de loteamentos de 1933, completada pelas leis de 1934 e de 1937. Tornando indispensavel a aprovação governamental dos planos de loteamentos, estabeleceu ela que à administração é licito introduzir neles as modificações úteis e impôr servidões no interêsse da segurança pública, da higiêne, da circulação ou da estética; e, ademais, exigir a reserva de espaços livres (praças, parques de jogos, etc.) e de lugares destinados a edifícios e serviços públicos. Quanto a êstes, como a lei francesa, declarou-os indenizaveis. Esclareceu, no entanto, que os reservados para espaços livres não o serão, a menos que o conjunto imposto pela administração represente superficie superior ao quarto da totalidade.

Acentuou-se, na exposição de motivos justificativos daquela lei, que "os loteamentos não são, com efeito, do ponto de vista da administração, mais que planos particulares de alinhamento: projetos de regularização de 
quarteirões, projetos de extensão de cidades ou mesmo de vilas novas. $\mathrm{Em}$ todos os casos, êles interessam à autoridade superior ao mesmo título, senão mais que as construções individuais". Daí, a necessidade da autorização. Os planos têm que submeter-se à administraçâo. que os examina e reconhece se satisfazem às condições exigidas pelo interêsse superior da higiêne, pelas facilidades da circulação e contigências de ordem estética, podendo exigir as modificações que se lhe antolhem úteis.

$O$ cuidado, que nisso deve ser posto, refere tratadista, obriga os loteadores a indicarem as servidões de interêsse público de toda natureza e de toda origem, que recáiam sôbre seus terrenos, tais como as servidões militares, as de alinhamento e as que resultem dos regulamentos das ruas. De tanto importância é isso que a inobservância daquela obrigação ẻ sancionada pela possibilidade do decreto da nulidade das vendas. É o caso, e assim foi julgado, de inadimplemento das formalidades legais, quando se trate, por exemplo, de zona reservada, para utilização militar (5).

5. No projeto de lei reguladora do loteamento de terrenos, em 1936 apresentado à Câmara dos Deputados do Brasil, teve-se em mira idêntico propósito. Eis o motivo pelo qual se dispõs no paragr. 1 do art. 1 daquele projeto:

"Tratando-se de propriedade urbana, o plano e a planta do loteamento, determinando direção, largura e extensão de ruas, avenidas, praças, jardins, parques, espaços livres diversos, quadras, lotes, alturas e distancias das edificações, proporcionalidade destas com as das áreas de cada lote, servidões reciprocas dos edificios visinhos, higiênicas ou estéticas, distribuição de agua po-

(5) Albert Grillet, Traité Pratique des Lotissements au Maroc, ed. Recueil Sirey (Paris, 1938), pág. 59. 
tavel, rêdes de esgotos, canalizações de gaz e eletricidade, saneamento do sólo, etc., serâo, previamente, submetidos à aprovação da Prefeitura Municipal e, se fôr caso, das autoridades sanitárias e militares, no que lhes tocar".

Resumiu-se êsse tópico do projeto no seguinte texto do decreto-lei n. 58, de 10 de dezembro de 1937:

"Tratando-se de propriedade urbana, o plano e planta do loteamento devem ser previamente aprovados pela Prefeitura Municipal, ouvidas, quanto ao que lhes disser respeito, as autoridades sanitárias e militares".

Quer isso dizer que o plano e a planta dos loteamentos têm que elaborar-se de acôrdo com os dispositivos dos códigos ou leis de obras municipais, que devem dispôr a respeito no todo e nas particularidades.

No que a lei brasileira se distanciou das demais, no desiderato de garantir os adquirentes de lotes, foi no estatuir, no art. 3, que " $\alpha$ inscrição (do memorial e plantas no registro imobiliário) torna inalienavel, por qualquer titulo, as vias de comunicação e os espaços livres constantes do memorial $e$ da planta". Com êsse registro, bem ponderou Pontes DE MIRANda, verificou-se "a perda da individualidade objetiva do terreno loteado e a aparição das individualidades objetivas dos lotes." Esse é o prímeiro ef eito. " $O$ segundo é a inalienabilidade absoluta das vias de comunicação e dos espaços, isto é, tratos de terra deixados livres no memorial e na planta. Não há, no loteamento, qualquer idéia de comunhão, ainda pro diviso. As vias de comunicação são abertas ao público e os espaços, como praças, lugares para arborização, ou reservatórios de agua, são públicos".

E acrescentou:

“Tem-se entendido que as vias de comunicação e os espaços livres somente se tornam públicos por ato dos interessados, entregando-os à Pprefeitura Municipal. De modo nenhum. A aprovação do loteamento faz públicas as vias de comunicação e públicos os espaços livres, cont 
a ressalva de serem ultimadas pelos loteadores as obras das vias de comunicação e dos espaços livres e da modificabilidade segundo o decreto-lei n. 58" (6).

O sistema da lei brasileira, qual se infere do tápido exame, que acaba de ser feito, tem como resultado a eficiente proteção dos direitos dos adquirentes dos lotes e publicização, se assim se póde dizer, da propriedade dos espaços livres, ruas, praças, parques, etc.

6. Não se póde realmente encarar o problema por outro prisma. Eis porque, na Alemanha, goza a autoridade administrativa de poderes consideraveis no apreciar os planos de loteamentos urbânos. Cabe-lhes lá examiná-los atentamente e quanto o exija o interesse coletivo, de molde a determinar aos loteadores quais as areas a serem reservadas e constituintes dos espaços livres, para a comuna, sem indenização de nenhuma espécie. Nãu poderão chegar os poderes da administração pública ao arbítrio de tomar para si a parte do leão, frustrando, por completo, o objetivo dos loteadores, levando-os à desistência do empreendimento. Ela não poderá fazer reservar para o estabelecimento de praças, de jardins ou de vias de comunicações, e para o mais que deva atender a outra necessidade do interêsse público, superficie de terrenos excedente de $25 \%$ ou de $35 \%$, confórme as construções projetadas devam ser compactas ou disseminadas.

Terão os loteadores, nessas condições, da fazer o abandono gratuito de partes limitadas de seus terrenos; mas as autoridades administrativas bem podem considerar dispensavel essa reserva, tais sejam as circunstâncias especiais do caso. Quando isso aconteça (e o que se diz é tendo em conta os textos da lei de 22 de setembro de 1933) licito se torna à autoridade administrativa impôr

(6) Pontes de Miranda, Tratado de Direito Predial, ed. José Konfino, vol. IHI (Rio de Janeiro, 1948), pág. 107, paragr. 31. 
aos loteadores o pagamento, em dinheiro, de quantia correspondente ao sacrificio que, para êles, representaria a cessão gratuita dos terrenos destinados aos espaços livres.

7. Há, pois, que conciliar o interêsse dos loteadores com o interêsse público. Desde que êles destinam a sua propriedade particular ao desenvolvimento das cidades ou vilas, de tal modo que, para aproveitá-la com o maior rendimento, possivel, a transformam em plano urbâno ou suburbâno, o que é indiferente, criando, ao mesmo passo, novos encargos e ônus para o município, demasia não é que contribuam com parte daquela propriedade, abrindo mão dela a bem do interêsse público, para o êxito de seus empreendimentos interesseiros.

Não têm faltado, como é natural, os que imaginem, em face da lei brasileira, que inadmite o aproveitamento, pelo poder público, de qualquer parcela da propriedade particular, sem prévia indenização, que, aprovados os planos de loteamentos pelas municipalidades, os espaços livres, destinados às praças, ruas, vias de comunicações, etc. continuam no dominio dos loteadores; e que esta situação subsistirá até que se efetue a desapropriação por utilidade ou necessidade pública (7).

Examinada a questão por êsse ângulo, ainda assim se apresentariam aspectos de não menor relevância quanto à situação dos loteadores com os adquirentes de seus lotes. Os que tiverem frente para as vias, ruas ou praças públicas, têm, desde logo, facilidade de comunicação com as ruas da vila ou da cidade. Mas os lotes, traçados no interior dos terrenos, sem frente para as ruas ou praças, enfrentando com vias ou ruas do dominio particular dos loteadores, ficariam sujeitos ao arbitrio dêstes, de modo que lhes seria licito, a qualquer momento, cortar-lhes as comunicações, por contidos dentro de terrenos encravados

(7) Waldemar Ferretra, $O$ loteamento $e$ a venda de terrenos em prestações (São Paulo, 1938), pág. 116, n. 16. 
na propriedade particular, deixando-os destituidos de saidas públicas para as ruas públicas. Seria essa situação incompativel com o regime dos loteamentos de terrenos particulares a fim do seu aproveitamento coletivo pelos adquirentes dos seus lotes.

8. No âmbito do direito privado, aquelas ruas c praças, os espaços livres consignados nos memoriais e plantas de loteamentos, têm destino específico - o de serventias de trânsito ou de passagem entre os adquirentes dos lotes com as ruas vias públicas, de molde a permitir -lhes comunicação com os centros urbânos, a que acedem os novos quarteirões ou bairros e as ruas em que êles se dividem, pela propria necessidade de aproveitamento lucrativo da divisão e subdivisão do terreno. Mas não somente a isso se destinam, senão igualmente à intercomunicação dos lotes e de seus adquirentes.

Evidente é que essas ruas e praças. abertas em terrenos particulares, se lançam, de primeiro, por conveniência dos loteadores. Sem arruamentos incompreendem-se os blócos residenciais urbânos como os rurais sem estradas. Chamam-se tais ruas - de ruas particulares; e em verdade êste qualificativo lhes é impróprio, ainda mesmo que, por ato da autoridade municipal, ainda não se hajam oficializado. Ruas públicas é que elas efetivamente são, desde que oferecidas ao público como de serventia de passagem ou de trânsito. Não se podem haver como simples atravessadouros particulares, porque são muito mais do que tais, desde que destinadas ao uso do povo. Para que, decidiu acórdão de 3 de março de 1941, do Tribunal de Apelação de Belo Horizonte, uma rua se repute via pública, não se faz mistér decreto: basta que seja aberta ao uso público sem restrições (8).

(8) Retvista Foren'se, do Rio de Janeiro; vol. 86, de 1941, pág. 641 . 
9. Admitindo que, efetuado o loteamento do terreno urbâno, arruado de molde a facilitar aquela operação, expostos os lotes à aquisição do povo, os espaços livres de intercomunicação deles entre si, como com as vias de comunicação com a cidade, não se convertessem, só por isso, em ruas públicas, a ninguem seria licito contestar que êles seriam, necessariamente, servidões de passagem ou de trânsito, porque a isso inequivocamente destinados. É antigo o conceito de que a simples serventía do prédio se transmuda em servidão verdadeira, desde que alienado êste, por manifestação da vontade de ambos, e não estipulado o contrário (9).

Aliás, na própria venda ou no compromisso dos lotes, ao individualizar o de que se trate, descreve-se indicando-se-lhe o número, referindo-se lhe as linhas divisórias, dando-o como tendo frente para a "rna" tal ou qual, de tal quarteirão ou gleba. Indicando-se em tais termos a rua, avenida, alameda ou praça, para que faça frente, indisfarçavelmente se extrema a natureza do espaço livre por que transitará todo o mundo afim de comunicar-se com o lote vendido ou simplesmente comprometido.

Mais se evidência êsse objetivo quando intuitivamente se percebe a impossibilidade do loteamento de terrenos urbânos sem se ministrar aos lotes os meios de comunicação com as vias públicas.

Entram, por isso mesmo, aqueles espaços livres $\mathrm{n} a$ posse dos adquirentes dos lotes, de molde a assistir-lhes direito de impedir que a empresa loteadora lhes vede a trânsito livremente.

10. No âmbito do direito público, é da competência privativa das câmaras municipaìs o plano de arruamento urbano e sua execução: êsse é o principal serviço público

(9) Didimo Agaprto da Veiga Junior, As servidóes reais, ed. Garnier (Rio de Janeiro, 1887), pág. 33, n.34. 
da cidade, em toda sua complexidade e em todas as suas particularidades. Sem êle ela se torna incompreensivel. A cidade resulta do conjunto de ruas, praças, avenidas, largos, praças, jardins, ostentando as casas de habitaçõe:; de sua população, dos estabelecimentos comerciais e industriais, dos estabelecimentos públicos, etc. Sem êsse sistema a cidade não passa de simples palavra.

Cabe às câmaras municipais legislar sôbre isso e sôbre as edificações particulares, como é notório; e nertence aos seus agentes executivos - os prefeitos municipais, a execução dos serviços e obras públicas, quer diretamente, por administração, quer indiretamente, por via de concessões.

Quando o proprietário de terrenos particulares se propõe loteá-los, elaborando o plano urbanistico, por via do qual se obriga a abrir as ruas, avenidas, praças, jar. dins, parques, etc. que lhe permitirão vender os lotes, celebra êle, evidentemente, com o Municipio, contrato por via do qual êste lhe concede autorização para, por sua conta e risco, e a bém de seu particular interêsse, abrir aquelas ruas, avenidas, praças, jardins, parques, etc., que caberia ì Prefeitura Municipal, em cumprimento de deliberação da Câmara Municipal, aceitar, aproveitando-se de terrenos municipais ou, mesmo, de terrenos particulares.

Estes, para êsse objetivo, teriam que ser desapropriados. Desde que, porém, o proprietário dos terrenos, de sua livre e espontânea vontade, e mais no seu interêsse particular do que no interêsse do Municipio, neles traça e executa as ruas, avenidas, praças, etc., formando os quarteirões, divididos em lotes com frente para elas, é verdade que êle oferece, em troca das vantagens que busca com as vendas dos seus lotes, aqueles espaços livres e os entrega à coletividade.

Não tem, não póde ter outro significado o projeto de loteamento. Aprovado êle e expedido o alvará ou ato necessário para a sua execução, as ruas, avenidas, praças, 
largos, jardins, etc., se incorporam ao patrimônio municipal.

Nestas pégadas caminhou Washington Azevedo, ao tratar dos espaços livres, contendo parques. Como obtê-los? O primeiro método, respondeu, é naturalmente a aquisição; e esta pode dar-se por varias maneiras, a saber: a) pela compra, desapropriação ou sistema de taxas de benefíicio; b) pela doação; e c) pela lei de subdivisão de terrenos. Este, acentuou aquele tradista, é o caso mais provavel. "Na lei de subdivisão de terrenos deve haver uma cláusula que obrigue a cada pessoa ou companhia, que subdivide seus terrenos, a deixar, pelo menos, dez por cento da área para espaços livres. A lei de subdivisão do Rio de Janeiro obriga a cada pessoa que subdivide seus terrenos em lotes a deixar trinta por cento da área para espaços livres. Espaços livres neste caso equivalem a ruas, praças e parques" (10).

Deixando os espaços livres abertos e, desde logo, entregues aos adquirentes de seus lotes e ao transito público, com isso retribue o proprietário dos terrenos divididos ao Municipio a mercê que lhe faz e os Iucros que lhe proporciona com a venda dos seus lotes, quando não ainda com o financiamento das edificações, que o decreto-lei n. 58 , de 10 de dezembro de 1937, permite que se conjugue com o compromisso de venda dos lotes a prestações.

11. Aquela lei obriga os proprietários ou co-proprietarios de terras rurais ou terrenos urbânos, que pretendam vendê-los, divididos em lotes e por oferta pública, mediante pagamento do preço a prazo, em prestações sucessivas e periodicas a depositar, no registro imobiliário da respectiva circunscrição, - com o plano e planta do loteamento, previamente aprovados piela Prefeitura Municipal, ouvidas.

(10) Washincton Azevedo, A organizaçấo técnica dos Municipios, ed. Irmão Pongetti (Rio de Jeneiro, 1935), pág. 134. 
quanto ao que lhes disser respeito, as autoridades sanitárias e militares - memorial contendo:

a) a denominação, área, limites, situação e outros caracteristicos do imóvel;

b) a relação cronológica dos titulos de dominio, desde trinta anos, indicando natureza e data de cada um, números e datas das transcrições;

c) o plano do loteamento, de que conste o programa de desenvolvimento urbâno, ou de aproveitamento industrial ou agrícola, referindo, nesta última hipótese, a qualidade das terras, aguas, servidões ativas e passivas, estradas e caminhos, distância da séde do municipio e das estações de transporte de acesso mais fácil.

Esse memorial e os mais documentos, que deven acompanhá-lo, depois do processo estabelecido na lei, inscrever-se-iam no registro imobiliário. Transmudou, porém, o art. 178, c), n. VI, do decr. n. 4.857, de 9 de novembro de 1939, aquela inscrição em averbação.

12. $O$ ato de registro (inscrição ou averbação), pelo na lei disposto, no art. 3, "torna inalienavel, por qualquer título, as vias de comunicação e os espaços livres constantes do memorial e da planta". Padece, em tais termos, restrição insígne o direito de propriedade do loteador sôbre as vias de comunicação e espaços livres, conservando-o em inteira plenitude quanto aos lotes, êstes, sim, destinados à venda, mediante o pagamento do preço em prestações periódicas e continuas.

Teve o texto, assim concebido, o escôpo de assegurar aos adquirentes de lotes, como a todo o mundo, o direito de servirem-se das vias de comunicação entre êles, ou entre êles e as demais vias públicas em demanda do centro urbâno a que se subordinaram. Esse direito seria precário se, a qualquer momento, fosse licito ao loteador transferir o seu domínio sôbre aquelas vias de comunicação, tornando impossivel o aproveitamento dos lotes já vendidos ou simplesmente comprometidos. 
Eis porque, no $\S 4$ do art. 1, o decreto-lei n. 58, de 10 de dezembro de 1937, preceituou que "o plano de loteamento poderá ser modificado quanto aos lotes não comprometidos e o de arruamento desde que a modificação não prejudique os lotes comprometidos ou definitivamente adquiridos, se a Prefeitura Municipal aprovar a modificação". Mas, nessa hipótese, "a planta e o memorial assim aprovados serão depositados no cartório do registro para nova inscrição, observando-se o disposto no art. 2 e parágrafos", de molde a poderem os interessados impugnar a modificação.

Esta, por tal modo restrita, não poderá, em caso algum, realizar-se com ofensa dos direitos de terceiros, por ser admissivel, quanto ao arruamento, somente quando "não prejudique os lotes comprometidos ou definitivamente adquiridos".

13. Declarando inalienaveis, por efeito do registro do memorial e da planta, as vias de comunicação e os espaços livres dêles constantes, colocou-os a lei fóra de comércio, com torná-los inegociaveis.

Ora, pelo disposto no art. 520, n. 111, do código civil, perde-se a posse das coisas pela perda, ou destruição delas, "ou por serem postas fóra do comércio"; e o art. 69 tem como "coisas fora do comércio as inuscetiveis de apropriação, e as legalmente inalinenaveis".

Logo, e a conclusão é irresistivel, desde o momento em que o memorial e a planta de loteamento se registram, as vias de comunicação e os espaços livres, ex vi legis, se tornam inalienaveis. Em consequência, são postos fóra do comércio; de onde a perda, para o loteador, de sua posse sôbre êlas. 